\title{
Midwife's Role in the Mother-to-Child Transmission Prevention Program in Primary Health Care in Yogyakarta
}

\author{
Niken Meilani ${ }^{1 *}$, Nanik Setiyawati ${ }^{1}$, Sammy Onyapidi Barasa ${ }^{2}$
}

\author{
1Poltekkes Kemenkes Yogyakarta, Indonesia, ${ }^{2}$ Nursing Department, Kenya Medical Training College, Chuka \\ Campus, Kenya, East Africa
}

\begin{abstract}
Curing and eradicating Human Immunodeficiency Virus (HIV)/Acquired Immunodeficiency Syndrome (AIDS) are to the core principles of the United Nations' Sustainable Development Goals (SDGs). The incidence of HIV in the world remains high. Although midwives play a pivotal role in PMTCT implementation, the factors associated with midwives' role in its implementation are not well understood. The aim of this study was to determine factors associated with midwives' role in implementation of PMTCT. This study used a cross-sectional design. The subjects were 80 midwives at 14 primary health care in Yogyakarta City, Indonesia. The study was conducted from April to August 2017. Data were analyzed through univariate, bivariate with chi-square and Fisher's exact test, multivariate with logistic regression. The results showed that $47.5 \%$ of midwives were in the poor category regarding implementation of PMTCT. Information availability through socialization ( $p$-value $=0.047$ ) and knowledge level $(p$-value $=0.016$ ) were found to be related to PMTCT implementation. There was no relationship between age, length of work, education level, marital status, availability of information, midwife's attitude, perception of the availability of facilities and institutional support with midwife behavior in PMTCT implementation. Multivariate analysis showed that level of knowledge was the most dominant factor affecting PMTCT implementation (OR $=6.2 ; \mathrm{Cl} 95 \%=1.8-21.4)$. We recommend that efforts should be made to continuously improve the knowledge of midwives on PMTCT implementation through peer support and training in order to achieve sustainable development goals.
\end{abstract}

Keywords: Human Immunodeficiency Virus, midwives, pregnant, prevention

\section{Introduction}

The impact of Human Immunodeficiency Virus (HIV), the virus that causes Acquired Immunodeficiency Syndrome (AIDS), is still a major global public health concern. For instance, as of 2018, nearly 37.9 million individuals were living with the virus. However, there are persistent renewed efforts and commitments to halt and reverse the HIV pandemic. This has been seen in efforts such as the Sustainable Development Goals (SDG-3) which aims at ensuring universal access to HIV prevention services and to end HIV as a global threat by the year 2030. In the year 2018 out of the 1.7 million new HIV infections reported worldwide, 160,000 of them were among children aged 0-14 years. ${ }^{1}$

According to the Indonesian AIDS Committee in 2015, only five people were known to be suffering from AIDS in Indonesia in 1987. However, the number of

How to Cite: Meilani N, Setiyawati N, Barasa SO. Midwife's role in the mother-to-child transmission prevention program in primary health care in Yogyakarta. Kesmas: Public Health Journal. 2019; 14 (2): 88-94. (doi: 10.21109/kesmas.v14i2.2774)
AIDS cases in 2007 had jumped significantly, up to 17,699 cases, and 3,586 died. HIV attacks the immune system and damages a subtype of white blood cells called $\mathrm{T}$ lymphocyte or $\mathrm{T}$ cells, resulting in immunodeficiency and ended with AIDS. 2,3

In 2014 there were 501,400 cases of HIV/AIDS in Indonesia. People suffering from HIV/AIDS were spread throughout 32 provinces and 300 sub-regions/cities. The majority of people suffering from the disease were in the reproductive range of 15-29 years old. Today, the number of HIV/AIDS cases being reported in Indonesia is still just the tip of the iceberg. The estimated number of actual cases has reached 270,000 people and in Yogyakarta, and the incidence of HIV continues to rise annually.2,4

Vertical transmission (mother-to-child) is a major pathway for HIV infection in children. World Health

Correspondence*: Niken Meilani, Poltekkes Kemenkes Yogyakarta, Mangkuyudan MJ III Street No. 304, Yogyakarta, Indonesia, 55143, Phone: +6274-374331, E-mail: nikenbundaqueena@gmail.com

Received : November $14^{\text {th }} 2018$

Revised : May $9^{\text {th }} 2019$

Accepted : July $15^{\text {th }} 2019$ 
Organization (WHO) has declared that without preventive interventions, $40 \%$ of babies born from infected mothers would themselves be infected. The focus of prevention is applied in three phases, namely pregnancy, labor, and breastfeeding. These three phases underscore the critical midwives role that play in Prevention of Mother-to-Child Transmission (PMTCT). Midwife's knowledge of HIV can be the basic foundation that influence people's attitude and behavior. However, there are still midwives with negative attitude and perception towards HIV/AIDS. Thus, it is paramount that it becomes part of their job to overcome HIV/AIDS with unique understanding and approach. Midwives' knowledge, attitude, and perception towards HIV are important determinants in overcoming the disease. ${ }^{5,6}$

A high coverage of HIV testing appears to be hampered by the failure of pregnant women to understand that testing is available. Good quality HIV pre-test information is central to ensuring that pregnant women know and accept reasons for testing and return to collect result, a prerequisite for those who positively tested to complete the program. ${ }^{7}$

This study aimed to describe how midwives in Mother and Children Health Clinics in the Primary Health Care implement the PMTCT program for pregnant women and factors influencing their role.

\section{Method}

This cross sectional quantitative study, covering 14 Puskesmas/primary health care conducted in Yogyakarta City from April to August 2017. All midwives working in primary health care in the Mother and Children Clinics were assessed. Only clinics already implementing the PMTCT program were involved. The primary health care was selected based on random sampling techniques towards all primary healthcare center in Yogyakarta. The sample size calculated were proportion with minimum sample size. There were 80 midwive respondents that were chosen through random sampling. Selected respondents were selected from a list from 14 primary health care midwives. Those who took part were provided a written consent to participate.

This study used the Precede-Proceed Model. ${ }^{8}$ Independent variables consisted of the midwives' sociodemographic characteristics, such as age, marital status, education level, work experience, HIV information available through lectures and outreach in the workplace, midwives' knowledge of HIV and PMTCT, plus their attitudes toward its implementation. As predisposing factors, Midwives' perceptions about institutional support of the program were listed as reinforcing factors, and the facilities' availability to implement PMTCT was listed as enabling factor. The dependent variable was the midwives' role.
A self-administered questionnaire was used in this study. Midwives' knowledge was measured through multiple choice questions. True statements were scored as 1 and false statements were scored as 0 . The scores were then classified into three categories to characterize the level of knowledge; including higher $(>70 \%)$; satisfactory $(56 \%-69 \%)$ and unsatisfactory $(<56 \%)$. The study used a Likert scale to measure attitudes and categorized them as positive and negative based on the mean. The scoring was as follows: a positive statement Agree $=2$, Disagree $=1$, and Hesitant $=0$. A negative statement Agree $=1$, Disagree $=2$ and Hesitant $=0$. Level of perception used a visual analog scale scored from 0 to 10. Perception on institutional support was categorized as supporting and less supporting. Perception on facility availability and PMTCT behavior was categorized as good and poor.

Descriptive statistics using frequencies and percentage were used to describe findings. Chi-square test or Fisher's exact test was applied to determine relationships between dependent and independent variables. Logistic regression was applied for all variables with $p$-value $\leq 0.25$ and to explain independent variables: midwives' socio-demographic characteristics (age, marital status, education, work experience, HIV information available through lectures and socialization in the workplace, midwives' knowledge of HIV and PMTCT, midwives' attitude to the implementation of PMTCT, midwives' perceptions on institutional support for the PMTCT program. The availability of facilities' for implementing PMTCT was strongly associated with the dependent variable that was the midwives' role in implementing the PMTCT.

Ethical clearance was obtained from the Ethical Committee Poltekkes Kemenkes Yogyakarta Number: LB.01.01/KE-01/XII/326/2017. A formal letter of permission for respondents included informed consent; they were informed that the data would be treated with utmost confidentiality.

\section{Results}

The study was conducted on 80 randomly selected midwives in 14 primary health care clinics in Yogyakarta City that were implementing the PMTCT program. The characteristics of the respondents are showed in Table 1.

Table 1 shows that the majority of midwives were younger than 28 years old $(53.8 \%)$, had Diploma 3 education in midwifery $(82.5 \%)$, were married $(55 \%)$, and had worked for less than seven years $(55 \%)$. The main source of HIV information among respondents was via college lectures $(72.5 \%)$.

Independent variables in line with the PrecedeProceed Model of health program planning and evaluation by L. W. Green were midwives' knowledge 
Table 1. Distribution of Respondent's Characteristics

\begin{tabular}{llcc}
\hline Characteristic & Category & Amount $(\mathbf{n}=\mathbf{8 0})$ & Percentage (\%) \\
\hline Age & $>28$ years old & 37 & 46.2 \\
\multirow{2}{*}{ Marital status } & $<28$ years old & 43 & 53.8 \\
& Married & 44 & 55.0 \\
\multirow{2}{*}{ Education } & Single & 32 & 40.0 \\
& Widow & 4 & 5.0 \\
\multirow{2}{*}{ Work experience } & Midwifery subject $D 1$ & 4 & 5.0 \\
\multirow{2}{*}{ Information availability about HIV } & Midwifery subject $D 3$ & 66 & 82.5 \\
& Midwifery subject $D 4 / S 1 / S 2$ & 10 & 12.5 \\
& $>7$ years & 36 & 45.0 \\
& through lectures & 44 & 55.0 \\
& through socialization in the workplace & 58 & 72.5 \\
& & 4 & 5.0 \\
\hline
\end{tabular}

Notes: HIV = Human Immunodeficiency Virus, D1 = Diploma 1 degree, D2 = Diploma 2 degree, D3 = Diploma 3 degree, $\mathrm{S} 1$ = Bachelor degree, $\mathrm{S} 2$ = Master's degree

Table 2. Midwives' Knowledge Level, Attitude, Perception and Behavior in Implementing Prevention of Motherto-Child Transmission

\begin{tabular}{|c|c|c|c|}
\hline Characteristic & Category & Number of Midwives $(n=80)$ & Percentage $(\%)$ \\
\hline \multirow[t]{3}{*}{ Knowledge level } & Higher & 8 & 10.0 \\
\hline & Satisfactory & 32 & 40.0 \\
\hline & Unsatisfactory & 40 & 50.0 \\
\hline \multirow[t]{2}{*}{ Midwives' attitudes toward PMTCT } & Positive & 30 & 37.5 \\
\hline & Negative & 50 & 62.5 \\
\hline \multirow[t]{2}{*}{ Perception on institutional support } & Supporting & 36 & 45.0 \\
\hline & Less supporting & 44 & 55.0 \\
\hline \multirow[t]{2}{*}{ Perception on facility availability } & Good & 43 & 53.8 \\
\hline & Poor & 37 & 46.2 \\
\hline \multirow{2}{*}{ Midwives' role in implementing PMTCT } & Good & 42 & 52.5 \\
\hline & Poor & 38 & 47.5 \\
\hline
\end{tabular}

Note: PMTCT = Prevention of Mother-to-Child Transmission

level, attitude, perception, experience and roles in implementing PMTCT as seen in Table 2. It showed that majority of midwives' knowledge was categorized as unsatisfactory $(50 \%)$. Most respondents had negative attitudes toward PMTCT $(62.5 \%)$ and perceived that the institutions where they worked were unsupportive of their efforts to implement PMTCT (55\%). Majority believed that there were enough institutional facilities to implement PMTCT $(53.8 \%)$ and a similar majority $(52.5 \%)$ held positive attitudes to PMTCT.

Bivariate analysis was used to analyze association between independent and dependent variables (Table 3 ). Table 3 shows that midwives $>28$ years old mostly implemented PMTCT in the poor category $(51.4 \%)$, while those aged $<28$ years old mostly $(55.8 \%)$ ranked as Good. Statistically, this variable significance, with only a p-value of 0.678 . Midwives who worked more than 7 years scored in the $50 \%$ category of PMTCT implementation, while those who worked less than 7 years were mostly "unsatisfactory." However this variable was also statistically insignificant, at $\mathrm{p}$-value $=$ 0.857 .

Midwives with one year of midwifery education
(Diploma 1) scored at 50\%, in between those who scored good and poor. Respondent with three years of midwifery education (Diploma 3 ) implemented PMTCT in the unsatisfactory range $(51.5 \%)$. Midwives with undergraduate midwifery degrees (Diploma 4), or more, mostly implemented PMTCT in a good category $(80 \%)$. Statistically, this variable was insignificant, with $\mathrm{p}$-value $=0.156$.

Married midwives mostly implemented PMTCT in the unsatisfactory category $(59.1 \%)$, while single and widowed midwives implemented PMTCT in a good category $(65.6 \%$ and $75 \%)$. This variable, was not statistically meaningful, at $\mathrm{p}$-value $=0.064$. Most respondents claimed that they never received information about PMTCT provided in their workplace. This variable was statistically significant $(p$-value $=0.047)$. For knowledge level variable, most respondents $(71.9 \%)$ with satisfactory knowledge, implemented PMTCT in the good category, while those with unsatisfactory knowledge levels tended to implement PMTCT in the below average or not good enough categories $(60 \%)$. This variable was statistically significant $(\mathrm{p}$-value $=$ 0.016). 
Table 3. The Relationship Between Midwife Characteristics, Knowledge Level, Attitude, Perception about HIV/AIDS vs. Their Role in Implementing Prevention of Mother-to-Child Transmission

\begin{tabular}{|c|c|c|c|c|c|c|c|c|}
\hline \multirow{3}{*}{ Variable } & \multirow{3}{*}{ Category } & \multicolumn{6}{|c|}{ Implementation of PMTCT } & \multirow{3}{*}{ p-Value } \\
\hline & & \multicolumn{2}{|c|}{ Good } & \multicolumn{2}{|c|}{ Poor } & \multicolumn{2}{|c|}{ Total } & \\
\hline & & $\mathrm{n}=42$ & $\%$ & $\mathrm{n}=\mathbf{3 8}$ & $\%$ & $\mathrm{n}=\mathbf{8 0}$ & $\%$ & \\
\hline \multirow[t]{2}{*}{ Age (years) } & $>28$ & 18 & 48.6 & 19 & 51.4 & 37 & 100 & $0.678^{*}$ \\
\hline & $<28$ & 24 & 55.8 & 19 & 44.2 & 43 & 100 & \\
\hline \multirow[t]{2}{*}{ Work experience } & $>7$ years & 18 & 50.0 & 18 & 50.0 & 36 & 100 & $0.857^{*}$ \\
\hline & $<7$ years & 24 & 54.5 & 20 & 45.5 & 44 & 100 & \\
\hline \multirow[t]{3}{*}{ Education Level } & D1 Midwifery & 2 & 50.0 & 2 & 50.0 & 4 & 100 & $0.156 *$ \\
\hline & D3 Midwifery & 32 & 48.5 & 34 & 51.5 & 66 & 100 & \\
\hline & $D 4 / S 1 / S 2$ & 8 & 80.0 & 2 & 4.8 & 10 & 100 & \\
\hline \multirow[t]{3}{*}{ Marital Status } & Married & 18 & 40.9 & 26 & 59.1 & 44 & 100 & $0.064 *$ \\
\hline & Unmarried & 21 & 65.6 & 11 & 34.4 & 32 & 100 & \\
\hline & Widow & 3 & 75.0 & 1 & 25.0 & 4 & 100 & \\
\hline \multirow[t]{2}{*}{ Information available through socialization } & Yes & 0 & 0 & 4 & 100 & 4 & 100 & $0.047 *$ \\
\hline & No & 42 & 55.5 & 34 & 44.7 & 76 & 100 & \\
\hline \multirow[t]{2}{*}{ Information available through lectures } & Yes & 29 & 50.0 & 29 & 50.0 & 22 & 100 & 0.634 \\
\hline & No & 13 & 59.1 & 9 & 40.9 & 58 & 100 & \\
\hline \multirow[t]{3}{*}{ Knowledge level } & Higher & 3 & 37.5 & 5 & 62.5 & 8 & 100 & $0.016^{*}$ \\
\hline & Satisfactory & 23 & 71.9 & 9 & 28.1 & 32 & 100 & \\
\hline & Unsatisfactory & 16 & 40.0 & 24 & 60.0 & 40 & 100 & \\
\hline \multirow[t]{2}{*}{ Attitude toward HIV/AIDS } & Positive & 16 & 53.3 & 14 & 46.7 & 30 & 100 & 1.000 \\
\hline & Negative & 26 & 52.0 & 24 & 48.0 & 50 & 100 & \\
\hline \multirow[t]{2}{*}{ Perception on facility } & Good & 26 & 60.5 & 17 & 39.4 & 43 & 100 & 0.189 \\
\hline & Poor & 16 & 43.2 & 21 & 56.8 & 37 & 100 & \\
\hline \multirow[t]{2}{*}{ Perception on institutional support } & Good & 19 & 52.8 & 17 & 47.2 & 36 & 100 & 1.000 \\
\hline & Poor & 23 & 52.3 & 21 & 47.7 & 44 & 100 & \\
\hline
\end{tabular}

*used Fisher's exact test

Note: PMTCT (Prevention Mother-to-Child Transmission), D1 Midwifery = Diploma 1 Midwifery, D3 Midwifery = Diploma 3

Midwifery, D4 = Diploma 4 degree, S1 = Bachelor degree, S2 = Master's degree S1 = Bachelor degree, S2 = Master's degree

The attitude variable included both those with positive and negative attitudes about implementing PMTCT, scored in the good category, yet this variable was not statistically significant $(\mathrm{p}$-value $=1.000)$. For perception variable on the most respondent facilities, those with good perception $(60.5 \%)$ tended to implement PMTCT in the good category, while those with poor perception $(56.8 \%)$, implemented PMTCT in the poor category. This variable was statistically insignificant $(\mathrm{p}$-value $=0.189)$.

Perception variable on institutional support showed that respondents who perceived institutions as good or poor implemented PMTCT in the good category. This variable was not statistically significant $(\mathrm{p}$-value $=$ 1.000). Bivariate analysis, concluded that the independent variables which statistically related to midwives' role in implementing PMTCT were knowledge level and information availability through socialization in the workplace.

Multivariate analysis was done to independent variables with (totaled $\mathrm{p}$-value $<0.250$ ). Result of multivariate analysis showed that level of knowledge is the most significant factor influencing midwives' roles in implementing PMTCT, (p-value $=0.003, \mathrm{OR}=6.2$, and CI $95 \%=1.8-21.4)$ as seen in Table 4.
Table 4. Multivariate Analysis Factors Affecting Midwife's Role in the Mother-to-Child Transmission Prevention Program

\begin{tabular}{lrrrrr}
\hline \multirow{2}{*}{ Category } & B & Sig. & $\operatorname{Exp}(\mathbf{B})$ & \multicolumn{2}{c}{$\mathbf{9 5 \%} \mathbf{C I}$ for $\operatorname{Exp(B)}$} \\
\cline { 4 - 6 } & & & & Lower & Upper \\
\hline Knowledge & 1.836 & 0.003 & 6.272 & 1.836 & 21.431 \\
Constant & -19.209 & 0.999 & 0.000 & & \\
\hline
\end{tabular}

Note: $\mathrm{CI}=$ Confidence Interval

\section{Discussion}

Vertical transmission of HIV from mother to child could be prevented by the PMTCT program. Midwives are professional health providers with important, direct roles to play in this regard. Yet, midwives' who implemented the HIV/AIDS prevention program that scored in the good category in this study totaled at just $52.5 \%$. This number showed that implementation of PMTCT has not been very successful. Thus, it coincided with study done in Africa where implementation of PMTCT was just $56.9 \%$ or very low. ${ }^{5}$

In the current study, as a part of PMTCT, most midwives counseled pregnant women to take the HIV test. They also offered informed consent and performed the counseling after the test. Most midwives did not 
involve the husbands. The midwives also did not use proper protection, e.g., gloves, as directed in the universal precaution standards. This coincided with study conducted in Medan City, where midwives' actions in dealing with PMTCT patients were not in accordance with existing PMTCT psychological and social support guidelines that midwives are expected to provide to HIV positive patients. ${ }^{9}$

There were several things that affected the midwives' ill-informed behavior. One was the low level of knowledge of HIV and PMTCT. More than $50 \%$ of respondents did not know that depleted counts of CD4 white blood cells (also known as T-lymphocytes) indicate immunodeficiency, a strong predictor of HIV infection. Likewise, studies conducted in Nigeria and Malawi revealed that pregnant women were frequently not given antiretroviral (ARV) drugs, nor were their CD4 counts ascertained, resulting in high maternal mortality. ${ }^{10}$ The midwives also did not know about the type of ARV that could be consumed by pregnant women, the transmission trajectory of HIV, or how to properly conduct a labor assessment for HIV-infected pregnant women. Thus, it was likewise consistent with a study conducted in Medan City, where midwife's knowledge of PMTCT was rated poor. ${ }^{9}$ Study by Mohammed, ${ }^{6}$ also showed a low midwife's knowledge of HIV PMTCT (65.7\%).

The primary source of information on HIV/AIDS for midwives in this study was college lectures. Midwives did not have up-to-date information regarding HIV prevention. Only $5 \%$ of midwives admitted having attended an outreach on PMTCT. This, then, was also consistent with the Medan City study that found just one midwife who had been trained in PMTC programs. ${ }^{9}$ Research conducted by Setiyawati and Meilani on the initiation of service providers to conduct HIV testing demonstrated it to be the most influential factor on the behavior of HIV testing in pregnant women, thus midwives need to understand these efforts. ${ }^{11}$

Data analysis in this study shows similiarity with demographic data, where majority of midwives' knowledge of HIV and PMTCT were in the low category (score $<56)$. The bivariate analysis also shows that the proportion of midwives who implemented PMTCT in the good category were those with enough or good knowledge, while those who implemented PMTCT in the unsatisfactory category were those with low levels of knowledge.

Knowledge is one of the predisposing factors for an efficient health program, according to L. W. Green's Precede-Proceed Model. As stated by Ogbanna K, Govender I, Tumbo J, "The high levels of knowledge of the PMTCT program and generally satisfactory implementation" or better practice is predicated on adequate knowledge" meaning that the health provider's knowledge affects the implementation of PMTCT. However, as this study highlighted, midwives' knowledge was not affected by how much information they had but by their experience in implementing PMTCT itself. Knowledge was evidently the strong indicator of behavior in implementing PMTCT. Based on multivariate analysis in this study, midwives with good knowledge implemented PMTCT four times more in a satisfactory way than those with poor knowledge. $5,12,13$

The study also found that midwives' behavior in implementing PMTCT was affected by the availability of information sources through socialization in the workplace. Information source availability was one of the enabling factors in the Precede Model. Many of the midwives had multiple sources of information regarding PMTCT. 8,12

Socialization in the workplace usually would contain work steps, and facility availability for implementation of PMTCT. Some studies declared that PMTCT implementation was closely related to facility availability. That study explained that in implementing PMTCT, a sufficient supply of latex gloves and clean water would decrease the fear to implement PMTCT. 5,12,13

Commensurate with the explanation above, in this study, there were sufficient supplies of latex gloves and clean water. What caused inadequate implementation of PMTCT, was the insufficient work periods and responsibilities of the midwives, as well as a lack of information sources about HIV and PMTCT provided by the institutions where the midwives worked. Nor did multiple sources of information translate into improved knowledge. In the future, standards of evaluation will be required to standardize the measures of service provision. Indicators should include funding, service providers, drugs, utilities, PMTCT activities, physical location, supervision, management, and training. ${ }^{6,14}$

Pursuant to numerous studies, there were factors affecting midwife behavior towards the implementation of PMTCT. Two of them were attitudes towards PMTCT and perception of institutional support. In this study, these variables were not statistically meaningful. Midwives' perceptions towards implementation of PMTCT were mostly supportive, even if some of them still felt insecure about it. A major problem they encountered was the limited time available. While for institutional support, most midwives claimed that there was enough support, integrating interventions for prevention of mother-to-fetus HIV transmission, delivery, and breastfeeding, along with other healthcare services, required excess time commitment. Also needed was time spent for improving midwife's knowledge of the male partner in PMTCT. ${ }^{15-17}$

In the previous studies, negative attitudes towards HIV/AIDS disturbed patients. ${ }^{18}$ Health workers' 
negative attitude to the disease made the patients, especially women, reluctant to do antenatal care. ${ }^{19}$ An overview of the effects of stigma on access to and utilization of care and prevention services is also felt by people living with HIV (PLWH). ${ }^{20}$ However, in this study, these variables were not statistically significant.

\section{Conclusion}

Midwives' knowledge levels about HIV/AIDS and PMTCT are mostly below average. They need more information on PLWHA health indicators, and monitoring their status, antiretrovirals, the risk of mother-child transmission, and the childbirth process of HIV/AIDS mothers. Most respondents had negative attitude to implementation of PMTCT. They had preconceptions toward institutional support, claiming that the institutions were less supportive of PMTCT. They also declared their perceptions of facility availability are included in the good category. They implemented PMTCT in the good category but the poor category was still high. Midwives with higher levels of knowledge of HIV/AIDS will be better equipped to apply PMTCT rather than midwives with less knowledge.

\section{Recommendation}

To optimize the PMTCT program, midwives need to improve their knowledge of HIV/AIDS and PMTCT. They also need workshops and outreach about the program and better regulation of the burden of work for midwives, so that they get more time to implement the PMTCT in more effective ways.

\section{References}

1. HIV.gov. The global HIV/AIDS epidemic [homepage on the Internet]. 2019. Available from: https://www.hiv.gov/hiv-basics/overview/dataand-trends/global-statistics

2. Kementerian Pemberdayaan Perempuan dan Perlindungan Anak Republik Indonesia. Kasus HIV/AIDS di Indonesia meroket [homepage on the Internet]; 2014. Available from: http://www.kemenpppa.go.id/index.php/page/read/30/385/kasus-hivaids-di-indonesia-meroket

3. Nasronudin. HIV\&AIDS pendekatan biologi molekuler, klinis dan sosial. Surabaya: Airlangga University Press; 2013.

4. Komisi Penanggulangan AIDS. Data HIV/AIDS DIY 2016 [homepage on the Internet]; 2016. Available from: http://aidsyogya.or.id/2016/data-hiv-aids/data-kasus-hiv-aids-diy-sdmaret-2016/

5. Ogbanna K, Govender I, Tumbo J. Knowledge and practice of the prevention of mother-to-child transmission of HIV guidelines amongst doctors and nurses at Odi Hospital, Tshwane District. South African family practice [serial on the Internet]. 2016; 58(5): 167-71. Available from: https://www.tandfonline.com/doi/full/10.1080/20786190.2016.1228561

6. Mohammed E Y F, Kever RT, Martins S D, Afolabi O, Bulama K U.
Knowledge, attitudes and practices of nurses on Prevention of Motherto-Child Transmission (PMTCT) of Human Immuno-deficiency Virus (HIV) in state specialist hospital, Maiduguri, Borno State. Internasional Journal of Nursing and Midwifery [serial on the Internet]. 2016; 8(2): 12-7. Available from: https://academicjournals.org/journal/IJNM/article-full-text-pdf/42B169F57392

7. Ujiji O A, Rubenson B, Ilako F, Marrone G, Wamalwa D, Wangalwa G, Ekstrom A M. Is 'opt-out HIV testing' a real option among pregnant women in rural districts in Kenya? BMC Public Health [serial on the Internet]. 2011; 11(3): 151. Available from: http://www.biomedcentral.com/1471-2458/11/151

8. Green L W. Health promotion planning an educational and environmental approach. Mountain View Toronto - London: Mayfield Publishing Company; 2010.

9. Harahap S, Tukiman, Syarah V. Perilaku bidan KIA/KB dalam pelaksanaan program Prevention of Mother-to-Child Transmission (PMTCT) di Rumah Sakit Haji Kota Medan tahun 2013. Jurnal USU [serial on the Internet]. 2015; 1(3): 2. Available from: https://jurnal.usu.ac.id/index.php/kpkb/article/view/5172

10. Okoli J C, Lansdown G E. Barriers to successful implementation of Prevention of Mother-to-Child Transmission (PMTCT) of HIV programmes in Malawi and Nigeria: a critical literature review study. The Pan African Medical Journal [serial on the Internet]. 2014; 19(10): 154. Available from: https://www.ncbi.nlm.nih.gov/pmc/issues/247193/

11. Setiyawati N, Meilani N. Determinan perilaku tes HIV pada ibu hamil. Jurnal Kesmas Universitas Indonesia [serial on the Internet]. 2015; 9(2): 3. Available from: http://jurnalkesmas.ui.ac.id/kesmas/article/view/565

12. World Health Organization. PMTCT strategic vision 2010-2015: Preventing Mother-to-Child Transmission of HIV to reach the UNGASS and Millennium Development Goals: moving towards the elimination of paediatric HIV; 2009.

13. Okike O, Jeremiah I, Akani C. Knowledge, attitude and practical general medical practitioners in port harcourt towards the prevention of motherto-child transmission. The Nigerian Health Journal [serial on the Internet]. 2011; 11(9): 3. Available from: https://www.ajol.info/index.php/nhj/article/view/90523

14. Both JMC, Roosmalen JV. The impact of Prevention of Mother-to-Child Transmission (PMTCT) programmes on maternal health care in resource-poor settings: looking beyond the PMTCT Programme - a systematic review. International Journal of Obstetrics and Gynaecology [serial on the Internet]. 2010; 117(12): 1444-50. Available from: https://www.ncbi.nlm.nih.gov/pubmed/20937071

15. Car L T, Velthoven M H V, Brusamento S, Elmoniry H, Car J, Majeed A, Atun R. Integrating Prevention of Mother-to-Child HIV Transmission (PMTCT) programmes with other health services for preventing HIV infection and improving HIV outcomes in developing countries. NBCI Journal [serial on the Internet]. 2011; 15(6): 6. Available from: https://www.ncbi.nlm.nih.gov/pubmed/21678382

16. Horwood C, Haskins L, Vermaak K, Pakathi S, Subbaye R, Doherty T. Prevention of Mother-to-Child Transmission of HIV (PMTCT) programme in KwaZulu-Natal, South Africa: an evaluation of PMTCT implementation and integration into routine maternal, child and women's health services. Tropical Medicine and International Health 
[serial on the Internet]. 2010; 15(9): 992-9. Available from: https://www.ncbi.nlm.nih.gov/pubmed/20561313

17. Auvinen J, Kylma J, Valimaki M, Bweupe M, Suominen T. Midwives' perspectives on male participation in PMTCT of HIV and how they can support it in Lusaka, Zambia. Midwifery Journal [serial on the Internet].
2014;
30(1):
17-27.
Available
from:

https://www.midwiferyjournal.com/article/S0266-6138(13)000466/fulltext

18. Turan B, Budhwani H, Fazeli P, Browning W R, Raper J L, Mugavero M J, Turan J M. How does stigma affect people living with HIV? the mediating roles of internalized and anticipated HIV stigma in thr effects of perceived community stigma on health and psychosocial. HHS Author Manuscripts [serial on the Internet]. 2018; 21(1):283-91.
Available from: https://www.ncbi.nlm.nih.gov/pmc/articles/PMC5143223/

19. Saki M, Kermanshahi S M K, Mohammadi E, Mohraz M. Perception of patients with HIV/AIDS from stigma and discrimination. Iranian Red Crescent Medical Journal [serial on the Internet].2015; 7(6): e23638. Available from: https://www.ncbi.nlm.nih.gov/pmc/articles/PMC4537784/

20. Badriah F, Tahangnacca M, Alkaf R, Abe T, Hanifah L. Implementation of program for the prevention of mother-to-child transmission of HIV in South Jakarta. Kesmas: National Public Health Journal [serial on the Internet].2018; 12(4): 159-64. Available from: http://journal.fkm.ui.ac.id/kesmas/article/view/1707 